\section{The Night Sky in August}

THE moon is full on August $11^{\mathrm{d}}$ at $6^{\mathrm{h}}$ and new on August $25^{\mathrm{d}}$ at $11^{\mathrm{h}}$. No star brighter than magnitude $5 \cdot 3$ is occulted this month. Lunar conjunctions with the planets occur as follows: August $12^{\mathrm{d}} 7^{\mathrm{h}}$ with Jupiter ; August $16^{\mathrm{d}} 5^{\text {h }}$ with Saturn; August $28^{\mathrm{d}} 23^{\mathrm{h}}$ with Venus. (In New Zealand and other parts of the southern hemisphere the planet is actually occulted by the moon.) Venus, the disk of which is slightly gibbous, is an evening star increasing slowly in brightness to its maximum (mag. - 4.3) in midOctober. On August 31, the planet is near the first magnitude star, Spica. Jupiter, visible throughout the night, is in opposition on August 21, when its distance from the earth is rather less than 373 million miles. Saturn, the ring system of which is fairly well open, rises about $21^{\mathrm{h}}$ in mid-August. The distant planet, Uranus, now in Aries, is occulted by the moon on August 18; the occultation, however, is not visible from the British Isles, but is possible to observers in Canada. On August 15, $\alpha$ Lyræ is on the southern meridian at $21^{\mathrm{h}} 0.5^{\mathrm{m}}$. This star, together with $\alpha$ Cygni and $\alpha$ Aquilæ, make a conspicuous triangle, with the Milky Way for a background. Between $\beta$ and $\gamma$ Lyræ, the Ring Nebula may be located with slight optical aid. The variable star Algol in Perseus is coming into convenient position for observation. Its variability may be observed about two hours before and after the following epochs : August $18^{\mathrm{d}} 2^{\mathrm{h}} ; 20^{\mathrm{d}} 23^{\mathrm{h}} ; 23^{\mathrm{d}} 20^{\mathrm{h}}$. The Perseid meteors characterized by their yellowish colour, rapid flight and trains in their wake, reach a maximum about August 10. The above times are given in U.T.; add $1^{\text {h }}$ to convert to Summer Time.

\section{Announcements}

Pror. C. R. Harington, professor of pathological chemistry, and Prof. W. W. C. Topley, professor of bacteriology and immunology in the University of London, have been appointed members of the Medical Research Council, in succession to Prof. A. J. Clark and Sir John Ledingham, who retire in rotation on September 30.

THE following elections to the Paris Academy of Sciences have recently been made: Prof. T. H. Morgan, For. Mem. R.S., director of the Wm. G. Kerckhoff Laboratories of the California Institute of Technology, Pasadena, foreign associate, in succession to the late Lord Rutherford; Prof. T. Levi-Civita, For. Mem. R.S., emeritus professor of mechanics in the University of Padua, foreign associate, in succession to the late Dr. G. E. Hale; Prof. E. G. Barrillon, professor of the theory of navigation in the Ecole d'Application du Génie Maritime, Paris, member of the Section of Geography and Navigation, in succession to the late Dr. Ch. Lallemand.

Mr. J. J. MACGregor has been appointed advisory economist for the West Midland Province at the Harper Adams Agricultural College. Mr. MacGregor graduated in agricultural science at the University of Glasgow in 1928 and has since been continuously engaged in the study of the applications of economics to the problems of agriculture. He has held appoint. ments in agricultural economics at Seale Hayne Agricultural College and the University of Cambridge, and for the past three years has been on the staff of the Oxford branch of the Dartington Hall Economics Research Department.

LIEUT.-Coloner W. L. HaRnett, formerly professor of surgery in the Medical College, Calcutta, and recently reader in surgery at the British Postgraduate Medical School, has been appointed medical secretary to the Clinical Cancer Research Committee of the British Empire Cancer Campaign. The scheme of clinical cancer research, which has already commenced, will embrace approximately seventeen thousand fresh cases of cancer annually occurring in the teaching hospitals and the specialized hospitals of the London area and the hospitals of the London County Council and the Middlesex County Council.

THE Royal Astronomical Society recently decided to publish a small circular entitled Occasional Notes, containing short articles written in non-technical style. It is hoped that three or four a year will be issued; and they should prove useful to those Fellows who find the Monthly Notices too specialized to read with profit. The first number, June, 1938, contains an account of the minor planet Hermes, discovered on October 28, 1937, and also a description of the quartz clock developed at the National Physical Laboratory, Teddington. A similar clock for the Royal Observatory, Greenwich, is in process of construction.

The third International Congress for Microbiology will be held in New York City on September 2-9, 1939. It is requested that those who contemplate attending the Congress should send their names to Dr. R. St. John Brooks, secretary of the British National Committee (Lister Institute, Chelsea Bridge Road, London, S.W.1).

THE fifteenth Annual Conference of the Association of Special Libraries and Information Bureaux will be held at Lady Margaret Hall, Oxford, on September 23-26. Joint Sessions with the International Federation for Documentation will be held on September 24 and 25. Further information can be obtained from the General Secretary, Association of Special Libraries and Information Bureaux, 31 Museum Street, London, W.C.1.

The Joint Committee on Materials and their Testing is organizing a meeting which will be held at the Institution of Electrical Engineers on November 25 next under the auspices of the Institution to discuss non-destructive testing. The subject has been divided into three sections, namely : magnetic and electrical methods; X- and gamma-rays; acoustical and general methods. Each section will be dealt with by authorities from Great Britain, the Continent and the United States. The meeting will be held under the presidency of Dr. A. P. M. Fleming.

Erratum. In the inscription of Fig. $1 b$-in Prof. Ruggles Gates' letter on "Chromosome Structure" in Nature of July 23, page 157, the words "split satellite" written by him were, we regret, printed as "split chromosome". 